\title{
NARRACJE MILITARNE W UKRAIŃSKIEJ POWIEŚCI POPULARNEJ
}

\author{
JAROSŁAW POLISZCZUK ${ }^{1}$ \\ (Uniwersytet im. Borysa Grinczenki w Kijowie)
}

Słowa kluczowe: retoryka militarna, powieść, pamięć, trauma, koncept wojny

Keywords: military rhetoric, novel, memory, trauma, concept of war

\begin{abstract}
Abstrakt: Jarosław Poliszczuk, NARRACJE MILITARNE W UKRAIŃSKIEJ POWIEŚCI POPULARNEJ. „PORÓWNANIA” 15, 2014, T. XV, s. 219-231. ISSN 1733-165X. Koncept wojny, walki, sprzeciwu, tak samo jak i refleksja na temat porażki i rezygnacji z niedawnej przeszłości, stanowi cechę charakterystyczną publikowanych ostatnio powieści ukraińskich pisarzy: Oksany Zabužko, Vasyla Šklara, Liny Kostenko, Sergiya Žadana. Retoryka wojny zostanie rozpatrzona na podstawie interpretacji dwóch głośnych książek, mianowicie Liny Kostenko Pamiętnik ukraińskiego szaleńca oraz Sergiya Pantiuka Wojna i my. Analiza tych utworów pozwala na ewentualny wniosek o zasadniczym znaczeniu retoryki militarnej w kulturze postkolonialnej, w tym także w obliczu globalizacji i totalnego wydziedziczenia. Nie można odmówić obydwojgu autorom pewnej prognozy profetycznej w kontekście ostatnich wydarzeń, to znaczy aktualnej wojny lokalnej toczącej się na Ukrainie.
\end{abstract}

\begin{abstract}
Jarosłav Polishchuk, MILITARY NARRATIONS IN THE UKRAINIAN POPULAR NOVEL. "PORÓWNANIA" 15, 2014, Vol. XV, p. 219-231. ISSN 1733-165X. The concept of war and struggle, similarly as the reflection of defeat and resignation from the recent past became the main topic of the novels of Ukrainian writers, e.g. Oksana Zabužko, Vasyl Šklar, Lina Kostenko, Sergiy Žadan, etc. The researching of the military rhetoric in the article is based on the famous contemporary books The Notes of Ukrainian Crazy Man by Lina Kostenko and The War and We by Sergiy Pantiuk. The analysis of the novels gives us the possibility to find out and to understand the place of war in the post-colonial culture and in the space of globalization. The interesting fact is that, in their novels, both authors made some prognoses for the future, in particular regarding the contemporary local war in Ukraine.
\end{abstract}

\footnotetext{
${ }^{1}$ Correspondence Address: y.polishchuk@kubg.edu.ua
} 
Kwestia wojny, tak trwale i bogato zapisana $\mathrm{w}$ dziejach nadal pozostaje aktualna $\mathrm{w}$ humanistyce. Przede wszystkim dlatego, że militarne sytuacje nie należą wyłącznie do wspomnień z przeszłości, ale nadal się zdarzają, niekiedy całkiem nieprzewidywalnie. Ponadto, w warunkach XXI stulecia, kiedy, już się zdawało, że militarna pamięć zostanie oddana do archiwum i będzie interesować wyłącznie fachowców, zagrożenie wojną okazało się całkiem realne. Nawet, jeżeli nie jest to globalne zagrożenie związane z przysłowiową trzecią wojną światową, nagle apeluje do podobnego tragicznego doświadczenia sprzed lat, jak i do wcześniejszego konfliktu. Liczne lokalne konflikty wybuchające w XXI wieku w Europie, Azji, Afryce (Irak, Izrael, Czeczenia, Egipt, Tunezja, Bośnia itp.) ten sąd uwierzytelniają. W ostatnim czasie dołącza do wskazanych przykładów kryzys, który przyczynił się do otwartego, militarnego starcia na wschodzie państwa ukraińskiego.

Obserwowanie niepewnego i rozchwianego stanu współczesnego społeczeństwa, wciąż balansującego na krawędzi pokoju i wojny, skłania wielu uczonych ku nieoptymistycznej prognozie wobec perspektyw ludzkości. Cywilizacja, która osiągnęła doskonałość w postępach technicznych i technologicznych, okazała się niezdolna, by zachować własną stabilność, zagwarantować pokój oraz spokój na rzecz przyszłości. „Ludzkość weszła w okres krytyczny, z którego wyjście w wielkim stopniu będzie decydować o losie cywilizacji ziemskiej a, być może, i Kosmosu. Wybór skutecznych strategii zachowania się i rozwoju może zależeć i od tego, jak jednostka wyobraża siebie, swoją historię i swoje najgłębsze motywacje" 2 .

W światowej spuściźnie literackiej temat wojny został zaprezentowany bardzo solidnie, począwszy od starożytnych eposów (Iliada i Odyseja Homera), po Pieśn o Rolandzie, Rycerz w tygrysiej skórze Szota Rustaweli i in.). Warto wspomnieć, że już u progu XX wieku powstały dzieła, w których pisarze zobrazowali perspektywę militarnych konfliktów w skali globalnej, a także ich zgubny wpływ na całą ludzką cywilizację. Profetyczne wizje przedstawili wówczas Herbert George Wells w powieściach Wojna światów (The War of the Worlds, 1897) oraz Wojna w powietrzu (The War in the Air, 1908), Jack London w Żelaznej pięcie (The Iron Hell, 1908), Heinrich Mann w Poddanym (Der Untertan, 1914), Henri Barbusse w powieści Ogień (Le Feu, 1915). W tym rzędzie znalazły się również powieści Wilk stepowy (Steppenwolf, 1927) Hermanna Hesse, Tutaj to nie jest możliwe (It Can't Happen Here, 1935) Sinclaira Lewisa, Inwazja jaszczurów (Válka s mloky, 1936) Karela Čapka. W odróżnieniu od wielu utworów, zawierających opis zdarzeń wojennych bądź spostrzeżenia dotyczące psychologii jednostki w warunkach wojny, wspomniane powieści oferują coś innego, właściwie refleksję wobec stanu walki i pokoju, wobec perspektyw cywilizacji ludzkiej w ogóle. Z tego punktu widzenia dzieła te nie tylko wywołują zainteresowanie czytelnika intelektualisty, lecz mogą być interpre-

${ }^{2}$ A. Nazaret'ân, Antropologiâ nasiliâ ì kultura samoorganizacì̀: Očerkì po evolucionno-isstoričeskoj psikhologiì. Moskva 2007, s. 235. 
towane jako teksty o znaczeniu profetycznym, zawierają bowiem przepowiednie dotyczące przyszłości. Co więcej, tego typu utwory, jak uważa wielu współczesnych badaczy, można potraktować jako znaczące ostrzeżenia o dużym stopniu przewidywalności³.

Ponieważ ukraińskie pisarstwo przez długi okres reprezentowało rodzaj kultury prowincjalnej, to - $\mathrm{w}$ przeciwieństwie do literatur imperialnych - militarny czynnik zajmował w nim dosyć skromne miejsce. Kreślenie obrazu wojny nie jest mocną stroną ukraińskiej literatury. Temat wojny nie znalazł się w centrum tematycznym tej kultury (zwłaszcza w porównaniu z rosyjską czy nawet białoruską, które posiadają wybitnych autorów skupiających się na tematach wojennych). Gwoli sprawiedliwości, wypada podkreślić, że mimo ogromnej tragedii Ukrainy i Ukraińców doznanej w czasie dwóch wojen, zwłaszcza drugiej z nich (o tym przekonująco napisał amerykański historyk Timothy Snyder w niedawno wydanej książce o losach Europy Wschodniej w okresie reżimów totalitarnych ${ }^{4}$ ), obraz wojny $\mathrm{w}$ ukraińskiej literaturze, jak dotąd, pozostaje płaski, fragmentaryczny i wywołuje różne zastrzeżenia. Oczywiście, można z łatwością odnaleźć utwory, które zasługują na uwagę $\mathrm{z}$ tego punktu widzenia, na przykład rozsławiona w swoim czasie powieść Olesia Gončara Chorą̇̇owie (Прапороносui, 1946-1948). Jednakże nie zmienia to tendencji ogólnej, o którą nam chodzi. Fenomen militaryzmu w kulturze jest mocno skorelowany ze społeczeństwem totalitarnym, z promocją totalitarnej władzy, jak to niedawno udowodniła Iryna Zakharčuk, badając retorykę militarną $\mathrm{w}$ powojennej prozie ukraińskich pisarzy dwu pokoleń ${ }^{\text {. Od- }}$ powiadając na imperialne wezwanie do ekspansji i podboju, ukraińscy autorzy sięgali raczej po obronne chwyty retoryczne niż odzwierciedlali sytuacje dotyczące czynnej obrony.

W swoim czasie czynniki militarne zostały doskonale przyswojone przez literaturę rosyjską i radziecką, jako że militarny dyskurs jest tradycyjnie mocny w tej imperialnej kulturze. Jak twierdzi Ewa Tompson, siła imperium bezpośrednio przekłada się na moc jego fikcji artystycznej, stąd „agresywne postawy demonstrowane $\mathrm{w}$ sferach militarnej i politycznej znalazły również oddźwięk w powieściach" ${ }^{\prime}$. We współczesnej literaturze ukraińskiej może to być odbierane jako spadek minionego czasu. W tym wypadku należałoby mówić o „militaryzmie namiastkowym", co wskazuje na odzew z przeszłości i, być może na, w pewnym stopniu, związek współczesnych praktyk pisania ze strategiami, które zostały wy-

${ }^{3}$ Zob.: T. Motyl'eva, Roman - svobodnaâ forma. Moskva 1982, s. 362.

${ }^{4}$ Zob.: T. Snyder, Skrwawione ziemie. Europa między Hitlerem a Stalinem. Tłum. B. Pietrzyk. Warszawa 2011.

${ }^{5}$ I. Zakharčuk, Vìjna ì slovo (Militarna paradygma literatury socialìstičnogo realìmu): monografiâ. Luck 2008, s. 83-94.

${ }^{6}$ E. Thompson, Trubadurzy imperium. Literatura rosyjska i kolonializm. Przeł. A. Sierszulska. Kraków 2000, s. 133. 
pracowane $\mathrm{w}$ poprzednim okresie, $\mathrm{w}$ kontekście mocno zakorzenionych $\mathrm{w}$ społeczeństwie ukraińskim stereotypów (nadal funkcjonujących wśród starszego pokolenia).

Taras Vozniak twierdzi, że cały wiek XX to „historia jednej Wielkiej wojny”7, która toczyła się w Europie przez prawie stulecie i skończyła się dopiero w roku 1991, po upadku największego totalitarnego państwa, jakim był ZSRR. Nawiasem mówiąc, wniosek ten należy zweryfikować w kontekście agresywnej polityki Federacji Rosyjskiej i wywołanych przez nią lokalnych wojen w Czeczenii, Gruzji oraz ostatnio na Ukrainie. Uwzględniając te fakty, można zaryzykować pogląd, że „Wielka wojna” na Wschodzie Europy nie skończyła się do dnia dzisiejszego. Również w okresie pomiędzy pierwszą a drugą wojną światową, a także w czasie zimnej wojny czy innych rozlicznych powojennych napięć i konfliktów, retoryka militarna okazywała się bardzo przydatna. Co więcej, można powiedzieć, że cała współczesna kultura została przesiąknięta duchem militaryzmu.

W młodym państwie ukraińskim reaktualizacji motywów militarnych sprzyja konieczność wypracowania zbiorowej tożsamości. Jest to cecha ogólnego procesu scharakteryzowanego niegdyś przez Karla Jaspersa jako „niezadowolenie z historii"8, co zachęca do ponownego odczytywania przebiegu zdarzeń z przeszłości przez kolejne pokolenia. Chodzi między innymi o ugruntowanie tradycji narodowej - z jej bohaterami, bitwami, zwycięstwami i kultami. Dlatego w ostatnich latach w kulturze ukraińskiej pojawiły się liczne próby przewartościowania tradycji militarnej, a przede wszystkim wyzwolenia jej spod ciężaru tabu i wypełnienia nową treścią, która odpowiadałaby aktualnej sytuacji społecznej i politycznej. Oczywiście, na tej drodze pojawia się sporo sprzeczności, jednakże bez przewartościowania historii, bez dokonania rewizji jej najważniejszych faktów nie jest możliwe pomyślne budowanie nowej tożsamości zbiorowej Ukraińców. Dlatego koncepcja walki narodowo-wyzwoleńczej i działających w jej ramach postaci nadal pozostaje przedmiotem debat intelektualistów oraz budulcem dla nowej wizji historii Ukrainy. Jeżeli pisarze ukraińscy biorą się za kreślenie pewnych kart historii ruchu narodowego, to $\mathrm{w}$ ten sposób angażują się $\mathrm{w}$ proces formowania nowej świadomości zbiorowej, zdolnej do uwypuklenia we wspólnych dziejach Europy tych racji narodowych i regionalnych, które wcześniej nie zostały zauważone bądź były lekceważone.

Poza tym, w naszym stuleciu w sposób radykalny zmieniły się wyobrażenia o tym, jak i z pomocą, jakich narzędzi organizuje się wojny. „Kiedy myślimy o wojnach w XXI wieku, to nawet nie zauważamy, że współczesne wojny mają zupełnie inną naturę, niż dawniej - są to zarówno wojny informacyjne, jak i wojny ze

7 T. Voźńâk, Velika vijna v Êvropi ì perspektivi totalitariymu. „Ï” 2013. http://www.ji-magazine.lviv. ua/anons2013/Voznyak_Velyka-Vijna_v_Europi.htm (data dostępu: 11.10.2013).

${ }^{8}$ K. Jaspers, Smysl i naznačenie istorii. Pier. z niem. M. Levinoj. Moskva 1991, s. 277. 
stosowaniem znaczeń jako narzędzi, również cyberwojny"9 - pisze Taras Vozniak. Zatem znaki militarne we współczesnym świecie polityki oraz kultury są przekazywane w nowy sposób, nie bezpośrednio, tylko poprzez właściwy „kamuflaż”, co odzwierciedla się w przekazie medialnym. A przecież militarny dyskurs w tej postaci nie zmienia swojej wymowy, pozostaje skierowany na reorientację opinii całego społeczeństwa.

Spośród nowych utworów ukraińskiej literatury zauważymy niemało utworów zawierających składnik militarny. Wymienimy dla przykładu kilka pozycji, które zostały niedawno ogłoszone drukiem, a wywarły ożywioną dyskusję wśród krytyków i czytelników. Są to powieści Oksany Zabužko Muzeum porzuconych sekretów (Музей покинутих секретів, 2009)10, Vasyla Šklara Czarny kruk (Чорний ворон, 2009), Volodymyra Lysa Stulecie Jakowa (Столітmя Якова, 2010) oraz Solo dla Salomеi (Соло для Соломї, 2013), Sergiya Žadana Woroszyłowgrad (Ворошиловград, 2010), Liny Kostenko Pamiętnik ukraińskiego szaleńca (Записки українського самашедшого, 2011), Yuriya Ščerbaka Czas śmierciochrystów: miraże 2077 roku (Чac смертохристів: Міражі 2077 року», 2011), Sergiya Pantiuka Wojna i my (Biüна $i$ ми, 2012), Yuriya Vynnyčuka Tango śmierci (Танго смерmi, 2012), Andriya Kokotiukhy Czerwony (Червоний, 2012) i in. Rzecz jasna, mamy tu różny stopień zaangażowania militarnego, lecz wspólną cechą wymienionych utworów jest sięganie po retorykę wojenną, co wcześniej nie było charakterystyczne dla ukraińskiej powieści. Pisarze ukraińscy na różne sposoby mierzą się z wyzwaniem reinterpretacji militarnego doświadczenia z przeszłości i reaktualizacji właściwej warstwy retorycznej we współczesnym powieściopisarstwie, co w obecnych okolicznościach życia społecznego nabiera nowego znaczenia, zwłaszcza ze względu na "cichą" wojnę toczącą się na wschodzie i południu Ukrainy w roku 2014, po wygranej rewolucji godności. Czyżby pisarze potrafili przewidzieć te zdarzenia jeszcze kilka lat temu? Chyba nie. Chodzi o coś innego: potrafili wyczuć i wyrazić niepokój, zagubienie i zakłopotanie ukraińskiej opinii publicznej.

Biorąc pod uwage ograniczone możliwości badacza w ramach referatu naukowego, w ciągu dalszym skupię się na dwóch wybranych pozycjach spośród wyżej wymienionych książek. Będą to powieści Liny Kostenko Pamiętnik ukraińskiego szaleńca oraz Sergiya Pantiuka Wojna i my. Obie powieści różnią się stosunkiem do pokoleniowej przynależności jak również doświadczeniami autorów, stylem, układem kompozycyjnym. Tym, co je upodabnia jest czynnik militarny. W centrum uwagi autorów znajdują się kwestie sprzeciwu, obrony przed ewentualną

9 T. Voźńâk, op. cit. [przekład mój - J. P.].

10 W wersji polskojęzycznej ukazała się w roku 2012. Patrz: O. Zabużko, Muzeum porzuconych sekretów. Przeł. K. Kotyńska. Warszawa 2012. Wyjątkowość tej powieści znalazła uznanie u publiczności polskiej, o czym świadczy przyznanie autorce Nagrody Literackiej Europy Środkowej „Angelus” w roku 2013 we Wrocławiu. 
agresją z zewnątrz, które są zobrazowane w postaciach bohaterów z charyzmą, protagonistów obu utworów. Wspólną cechą dzieł jest także patos walki i sprzeciwu. Mimo że w obu przypadkach chodzi o przedstawicieli całkiem pokojowych profesji (programista Liny Kostenko oraz dziennikarz Sergiya Pantiuka), utwory cechuje sytuacja nieuniknionej walki, jako że bohaterowie znajdują się w centrum konfliktu. W końcu, powieści współczesnych pisarzy apelują w swoich intertekstualnych odwołaniach do tradycji powieści antywojennej, reprezentowanej przez wspomniane utwory H. G. Wellsa, J. Londona, H. Manna, H. Barbusse'a, E. M. Remarque'a i innych.

Według Liny Kostenko duch militaryzmu zdominował współczesny świat, podporządkował sobie prawie wszystkie sfery życia społeczeństwa. Dlatego w świecie przedstawionym powieści militarna retoryka oddaje właściwego ducha epoki. Bohater utworu jest stanowczo przeciwstawiony otoczeniu, ciągle czuje się $\mathrm{w}$ defensywie wobec nacisku z zewnątrz. Nie będąc w stanie wytrzymać napięcia spowodowanego przez taką konfrontację, zostaje usunięty na margines społeczny, staje się outsiderem. W swoim obrazie teraźniejszości Kostenko przedstawia między innymi nacisk propagandy masowej skierowany na łamanie woli i ewentualnej inicjatywy jednostki. Propaganda czynnie posługuje się językiem siły, przymusu, agresji. Przez retorykę militarną zyskuje na mocy i skuteczności. Według Liny Kostenko akcenty militarne zdominowały nie tylko ukraińskie media, lecz również warunkują przestrzeń informacji światowej.

W Europie już dzieci w szkołach uczą się bronić przed zbrodniarzami. Dziewczynki noszą z sobą gaz kieszonkowy. Dla kobiet wynaleziono biustonosze z kieszenią na pistolet $^{11}$.

Właściwie to media masowe stwarzają poczucie totalnego zagrożenia i prowadzą do uproszczenia wyobrażeń jednostki o świecie, banalizując podział na białe i czarne, na ofiary i sprawców. Z jednej strony, skutkuje to obawą przed ciągłym prześladowaniem, co nierzadko staje się prawdziwą obsesją, jak w przypadku bohatera powieści Liny Kostenko. Z innej strony, mobilizuje jednostkę, która musi wyrazić sprzeciw wobec agresora i przeciwdziałać nasilającej się absolutnej propagandzie. Nie przypadkowo przecież autorka utożsamia obraz aktualnej rzeczywistości z korridą. Kiedyś sięgnęła po tę analogię w wierszu z lat młodości Przyszłam na ten świat nie dla korrid (Я, що прийила у світ не для корид). Bohater-outsider stanowczo dystansuje się od udziału w paramilitarnym wyścigu, jakim jest życie w jego ogólnie przyjętym trybie. Wybiera natomiast izolację i osamotnienie. Ogólną charakterystykę teraźniejszości pisarka utrzymuje w barwach apokaliptycznych:

${ }^{11}$ L. Kostenko, Zapysky ukraïnskogo samašedšogo. Kiïv 2011, s. 110 [przekład mój - J. P.]. 
Rozwścieczone byki szaleją, z rykiem mkną po bruku, chwytają na rogi i rozrzucają wszystko, co trafi się na drodze. Najważniejsze - jeżeli już jesteś trafiony, staraj się odskoczyć na pobocze.

Jeżeli odbierać to jako metaforę, to odskoczyłem na pobocze. Leżę na uboczu współczesności, a ona pędzi dalej z zalanymi krwią oczyma. Za nią się gonią, kłują nożami i kijami, ona rozpaczliwie się broni, kręci głową, kogoś już wzięła na rogi, a oni ją biją, wysadzają bombami, rażą, prowokują. I ona ryczy, i pędzi, i wybucha szałem, i rozdeptani ludzie i narody jęczą, i nie ma Hemingwaya, który zobrazowałby tę krwawą fiestę współczesności ${ }^{12}$.

Krytyka, obserwując twórczość Liny Kostenko twierdzi, że w ostatnich latach stopień tragiczności jej utworów znacznie wzrósł, a obecne w utworach pisarki apokaliptyczne nastroje stały się bardziej wyostrzone i dramatyczne. Ludmyla Tarnašynśka pisze, że „tragizm ten - bez niegdysiejszej rozpaczy, bez ogolonego nerwu - chowa się wewnątrz własnego bolesnego Ja, jak w muszli, nierzadko tracąc na emocjonalnej bezpośredniości i lirycznym zabarwieniu"13. W analizowanej powieści widoczne jest nawarstwienie się dwu charakterystyk dotyczących światopoglądu autora i mentalności bohatera, a to z kolei przekłada się na kompletny obraz czasu, w którym żyjemy.

Relacje bohatera Liny Kostenko ze światem wypada ująć jako sytuację pogoni i ucieczki. Jednakże nie są one jednoznaczne. Retoryka militarna płynąca z mediów masowych jest o tyle skuteczna, że sam bohater nieświadomie zaczyna myśleć w jej duchu. To dotyczy nawet jego sądów o życiu prywatnym. Daje się we znaki swoista dyfuzja, kiedy nastroje powszechne dominujące $w$ społeczeństwie, a hodowane przez media, zostają przenoszone na poziom jaźni jednostki i warunkują indywidualne sądy, opinie, które z pozoru wydają się wolne od wpływów zewnętrznych. Dlatego nawet życie prywatne zostaje interpretowane w duchu militaryzmu. Oto jak bohater powieści myśli o własnej żonie: „Dyskutować z nią jest bez sensu. Ona jest jak bomba. Można ją rozbroić tylko przez pocałunek"14.

Liczne reminiscencje i rozważania dotyczące przeszłości zamieszczone w powieści Liny Kostenko wskazują na zakotwiczenie pamięci w dziejach narodu. Zdaniem autorki, czasem osiowym dla Ukraińców jest okres kształtowania się ich jako narodu. Pisarka pokazuje rozwój ruchu narodowo-wyzwoleńczego w XX wieku, jako historię bohaterskiej obrony wobec zewnętrznego wroga, postrzegając ją w kształcie binarnych opozycji swój/obcy, co odpowiada sytuacji otwartej lub ukrytej wojny. Jeżeli wobec przeszłości taki schemat wygląda na konsekwentny, to w ocenie teraźniejszości stanowczo nie wystarcza. Trudno tutaj o przejrzyste odpowiedzi na pytania, które nasuwają się po lekturze powieści: gdzie są granice

\footnotetext{
12 L. Kostenko, op.cit., s. 162-163 [przekład mój - J. P.]..

${ }^{13}$ L. Tarnašynśka, Ukraïnśke šìstdeśâtnytstvo. Profilì na tlì pokolìnnâ. Kiïv 2010, s. 46 [przekład mój J. P.]..

${ }^{14}$ L. Kostenko, op. cit., s. 350 [przekład mój - J. P.].
} 
pomiędzy ukraińską a inną tożsamością? Czy podziały wewnętrzne społeczeństwa ukraińskiego są tak samo poważne, jak zagrożenia z zewnątrz? Na czym polega ukraiński projekt modernizacyjny? Głównym zarzutem wysuwanym przez pisarkę wobec rodaków jest to, że stracili wolę sprzeciwu, że zrezygnowali z perspektywy walki, która jest nieuchronna i w ten sposób przerwali tradycję buntu, reprezentowaną w powieści przez legendę pokolenia lat sześćdziesiątych. Dlatego opcja buntu, jedynie uzasadniona $\mathrm{w}$ tych okolicznościach, kojarzona jest $\mathrm{z}$ narodowymi bohaterami z przeszłości. Oni, nawet zmarli, w sposób symboliczny nawiązują do ducha walki, mobilizują do działania, kształtują wolę. Są to „zmarli, którzy trzymają linię obrony"15. Kiedy wreszcie dochodzi do masowego zrywu po sfałszowanych wyborach prezydenta państwa, autorka stwierdza, że duch sprzeciwu zostaje przywrócony. Charakterystyczny jest finał utworu, zwłaszcza dwa końcowe zdania mające znaczenie ideowe w wymiarze całej powieści:

Wreszcie nastąpił nasz Dzień Gniewu.

Linię obrony trzymają żywi ${ }^{16}$.

Powieść Sergiya Pantiuka Wojna i my, która wygrała w ogólnokrajowym konkursie „Koronacja słowa - 2011” i została wydana w serii „Czerwone i czarne” następnego roku, jest warta uwagi w kilku aspektach. Jej nieco ekstrawagancki tytuł nawiązuje do słynnej powieści Lwa Tołstoja z 1869 roku pt. „Wojna i pokój” (w oryginalnym tytule widoczna jest gra słów - Wojna $i$ my vs Wojna $i$ mir). W przesłaniu ideowym Tołstoja najważniejsze są dwa akcenty: 1) stwierdzenie mocy imperialnej władzy; 2) akceptacja męskości jako podstawy dla zbudowania zbiorowej tożsamości narodu rosyjskiego. Ewa Thompson pisze o tym:

Szczególne oeuvre Lwa Tołstoja przekazywała imperialną władzę w sposób, który miał kluczowe znaczenie dla rosyjskiego postrzegania siebie. Tołstoj potwierdził męski aspekt rosyjskiego samopostrzegania oraz jego związek z przeszłymi zwycięstwami wojskowymi ${ }^{17}$.

Ukraiński autor jednakże nie posiada ambicji wielkiego, rosyjskiego poprzednika, choć aluzje militarne odgrywają w jego utworze nader ważną rolę. Powieść Wojna i my skądinąd apeluje do fundamentalnego tekstu rosyjskiej literatury, jest też celowo ustawiona wobec militarnej strategii ukraińskiego pisarstwa z okresu radzieckiego (Chorażowie Olesia Gonczara czy Ukraina w ogniu Oleksandra Dovženki). Reinterpretacja symboli militaryzmu nie sprowadza się do postmodernistycznej gry, jak sugeruje tytuł powieści, lecz operuje głównie na poziomie ludzkiej jednostki, która przeżywa wojnę jako wyzwanie i cierpienie w konkretnej sytuacji życiowej.

\footnotetext{
${ }^{15}$ Ibidem, s. 352.

${ }^{16}$ Ibidem, s. 414 [przekład mój - J. P.]

17 E. Thompson, op. cit., s. 133-134.
} 
Proza Pantiuka jest ułożona $\mathrm{w}$ trybie biograficznej spowiedzi bohatera. We właściwym znaczeniu nie odpowiada to gatunkowej normie powieści. Słabą stroną tego utworu jest artystyczna szkicowość i brak wykończenia. Zarówno tutaj, jak i w powieści Liny Kostenko, jest dużo refleksji o charakterze publicystycznym, co $\mathrm{w}$ pewnym stopniu obniża artystyczny efekt utworu. Epizody życia bohatera zostają wyeksponowane $\mathrm{w}$ taki sposób, ażeby zobrazować nieuchronny, dynamiczny, nieprzewidywalny konflikt jednostki ze światem zdominowanym przez militaryzm. Bohater od dzieciństwa zastanawia się nad totalnością wojny w świadomości ludzi (nawet w pieśniach ludowych, w zwyczajach ulicy itp.). Młodo trafia do wojska radzieckiego, gdzie jest zmuszony do uczestniczenia w wojnie lokalnej, spotyka się bezpośrednio ze śmiercią, a zatem zostaje na zawsze okaleczony moralnie i psychicznie. Jeżeli fabuła utworu określona została fragmentarycznie i niekonsekwentnie, to zakres problematyki etycznej zasługuje na poważny poziom epicki. Od prywatnego doświadczenia jednostki autor zmierza do szerszego planu zobrazowania wojny - tym razem nie jako tematu literatury pięknej, ale jako egzystencjalnego przeżycia człowieka, co zostaje uwypuklone na tle tragicznych doświadczeń narodu i całej zmilitaryzowanej epoki.

Według Pantiuka ukryta wojna nadal trwa, mimo że czasy są spokojne i pokojowe. Przynajmniej jego bohater wciąż żyje w strefie militarnego zagrożenia, czuje desperację, a zmuszony jest do zmobilizowania sił dla obrony i przetrwania. Jest zakładnikiem totalnej wojny i jednocześnie sam ucieka się do agresji wobec innych, skoro jest to konieczny warunek jego własnego przetrwania. Posttotalitarne, mocno skryminalizowane społeczeństwo na nowo aktualizuje militarne doświadczenie z przeszłości. Wydaje się, że wojna będzie trwała wiecznie, zmieniają się tylko kształty militaryzmu. Jego zgubny wpływ na bohatera powieści Pantiuka nie ulega wątpliwości. Sytuacja wojny demoralizuje go kompletnie.

Wojna nie może całkiem wyparować z życia tego, kto choć trochę żył nią. Dziś mówią, że nawet radiacja może być stopniowo usunięta $\mathrm{z}$ organizmu do zera. A wojna $\mathrm{z}$ serca nie. I właśnie wojna to Twoja jedyna rywalka, gdyż miłość do niej, nieprzedawniona i chroniczna, jest jak choroba ${ }^{18}$

- tak zwierza się protagonista powieści swojej żonie.

Wspomnienia wojny dostarczają dużo cierpień, ale zarazem wciąż się nasuwają, ponieważ bohater nie wyobraża sobie bez nich własnego życia. Na tym polega perfidia militaryzmu, kuszącego i odstraszającego jednocześnie. Poza tym, cierpienie piętnuje jednostkę $\mathrm{w}$ sposób szczególny. Bohaterowie obu analizowanych powieści - Liny Kostenko i Sergiya Pantiuka - są podobni w tej sferze, gdyż czują się odpowiedzialni za zbrodnie spowodowane $\mathrm{w}$ przeszłości. Ich psychika zostaje straumatyzowana, a mimo to wciąż konfrontuje się z „normalnością”. „Ludzie,

\footnotetext{
18 S. Pant'uk, Vìjna ì mi. Kiïv 2012, s. 130.
} 
którym przyszło wycierpieć krytyczną masę poniżeń (i którzy je przeżyli), nie mogą być uczciwymi obywatelami. Ja także nie jestem uczciwym obywatelem, bo cierpię"19, stwierdza protagonista powieści Kostenko.

Wyzbyć się szkodliwych skutków wojny można tylko przez terapię, którą staje się właśnie spowiedź, tym razem w kształcie narracji artystycznej. Pisanie powieści to próba wyzwolenia się z dokuczliwej presji świadomości wojennej, uniemożliwiającej doznanie przez bohatera zwykłych radości i przyjemności życia. Kluczowym zdarzeniem w tym trybie staje się spotkanie $\mathrm{z}$ psychoterapeutką Niką Polovą, najpierw wirtualne, bo poprzez korespondencję internetową (przychodnia psychoterapeutyczna zachowuje anonimowość w kontaktach z klientami), a później także osobiste, z przypominaniem dawnej, z lat dziecinnych, znajomości. Krok po kroku, uświadamiając sobie $\mathrm{w}$ obcowaniu z Niką totalność militarnej retoryki w życiu codziennym, bohater Sergiya Pantiuka próbuje znaleźć alternatywny dyskurs, w obrębie którego udałoby się mu zachować niezakłamaną tożsamość. Zastosowana terapia okazuje się niełatwa, gdyż koszmary z przyszłości wciąż przewijają się w jego refleksjach. Razem z bohaterem powieści swoistej terapii doznaje sama Nika Polowa: rewidując własną przeszłość, uświadamia sobie, na ile militarne standardy radzieckiego społeczeństwa zaważyły w jej życiu. Ona również ma potrzebę wyzbycia się zadawnionego lęku, ponieważ ciągle przeżywa sytuację obrony, prześladowania i zamknięcia. Poprzez odpowiedź Niki poznajemy inny, prywatny dramat, polegający na rywalizacji jednostki $z$ totalnym militaryzmem. Jest to w jej ujęciu historia „wojny z życiem”, nie mniej przerażająca i przekonująca niż historia tytułowego bohatera. Można by rozwinąc tutaj wątek genderowy, gdyż obydwie wersje walki z wojną w umysłach i zwyczajach - męska i żeńska zostają zrównoważone w kompozycji powieści, mimo że są bardzo różne w swojej istocie i odzwierciedlają odmienne oblicza traumy, spowodowanej dominacją męskości, brutalności i agresji w totalitarnym i posttotalitarnym społeczeństwie.

Wyzbycie się ducha militaryzmu okazuje niemożliwe, gdyż grozi utratą własnej tożsamości, budowanej na podstawie doświadczenia wojny. Protagonista powieści Pantiuka wciąż konfrontuje własne odczucia z tymi wyobrażeniami, które pochodzą z dzieciństwa i uformowały jego charakter (zabawy w wojnę, agresja dziecięca, rywalizacja rówieśników, konflikty z otoczeniem w okresie dorastania). $\mathrm{Z}$ innej strony zestawia własne, dramatyczne $\mathrm{w}$ istocie doświadczenie $\mathrm{z}$ tą uproszczoną, wręcz sielankową wizją wojny, która została ustanowiona przez masową propagandę w okresie ZSRR, według której wojna wyglądała na święto i patriotyczną paradę. Dlatego autobiograficzny bohater Sergiya Pantiuka jest mocno zdystansowany wobec militaryzmu z patosem, jego wizja wojny jest raczej sceptyczna, nacechowana gorzką ironią:

${ }^{19}$ L. Kostenko, op. cit., s. 96 
To tylko w prymitywnych filmach bohater biega i zabija dziesiątki czy nawet setki wrogów [...]. W rzeczywistości wszyscy jesteśmy tak samo bohaterami, jak i tchórzami. Po prostu każdy świadomie bądź nieświadomie pragnie przeżyć, choć o jeden dzień dłużej. Dlatego tak naprawdę walczymy nie tyle o wysoką ideę, choć i ona często jest obecna, ile o własne życie. I cała sztuka polega na tym, że realizować to należy na najwyższym szczeblu, wydobywając z głębi swej istoty wszystkie umiejętności, nawyki, całą rutynę życiową ${ }^{20}$.

Skompromitowanie wizji militaryzmu w powieści Wojna i my można interpterować jako akt polemiki z radziecką doktryną propagandową, która stanowczo sakralizowała militarne akcenty w kulturze. Jest to również gest polemiczny wobec etosu "dzikiego kapitalizmu", jaki nastąpił po upadku imperium radzieckiego, w latach 90. XX stulecia, odziedziczywszy od poprzedniego systemu politycznego i rozwijając na swój sposób kult siły, męskości i postawę agresywną wobec Innych. Pantiuk solidaryzuje się z patosem antywojennym, którym została przesiąknięta cała tradycja nowoczesności, począwszy od głośnych powieści Heinricha Manna, Ernesta Hemingwaya, Ericha Marii Remarqu'a i innych. Akcentuje przecież codzienność i banalność, które utkwiły w prywatnej pamięci protagonisty, jako właściwy wizerunek wojny. Jednocześnie jest zwolennikiem stanowczego protestu przeciwko przemocy, która stała się codzienną praktyką we współczesnym świecie, zwłaszcza w sytuacji posttotalitarnej. Problemu tego nie należy lekceważyć. Badaczy twierdzą, że traumy psychologiczne, moralne lub socjalne spowodowane przez przemoc, rzutowały na, co najmniej, trzy pokolenia ludzi radzieckich ${ }^{21}$. We współczesnym świecie takie traumy również są obecne, tylko nie zawsze są demaskowane i poddawane pod osąd opinii publicznej.

Warto wspomnieć, że w historii XX wieku ukraińskie doświadczenie wojny było przeważnie nacechowane tragizmem. Działo się tak przede wszystkim przez fatalną geopolityczną sytuację Ukrainy, choć nie warto lekceważyć także bierności ukraińskiej ludności, która właściwie nie miała czego bronić oprócz własnej rodziny oraz domu i nie podzielała propagandowego patosu patriotycznego. Cechowały tę sytuację, prócz agresji zewnętrznej, także rozłam wewnątrz narodu, represje władz stalinowskich, lęk, bezbronność i desperacja. Wszystko to wywołało w ukraińskim społeczeństwie trwałą, trudno uleczalną traumę, z którą próbują zmierzyć się współcześni pisarze, autorzy wymienionych wyżej powieści popularnych Oksana Zabužko, Yuriy Vynnyčuk, Sergiy Pantiuk i inni. Oficjalna radziecka literatura miała wielki grzech na sumieniu, dlatego że zrezygnowała z ukazywania dramatycznej i tragicznej strony wojny (odpowiednie opcje zostały w niej przemilczane bądź zmarginalizowane), a oferowała uproszczoną, paradową

${ }^{20}$ S. Pant'uk, op. cit., s. 10 [przekład mój - J. P.]

${ }^{21}$ D. Hapaeva, Gotičeskoe obŝčestvo. Stalinskoe prošloe v rossijskom nastô̂ŝem. „Kritičeskaâ massa” 2006, nr 1. http:/ / www.artpragmatica.ru/km_content/ ?auid=25 (data dostępu: 11.10.2013). 
wersję wojny. Tylko najwybitniejsi pisarze zdawali sobie sprawę ze strategicznego znaczenia podobnych strat. Oleksandr Dovženko jeszcze w swoich pamiętnikach $\mathrm{z}$ tamtego okresu ujął wojnę jako tragedię całego narodu, widząc jej przyczyny $\mathrm{w}$ zacofaniu społeczeństwa i nikłym duchu patriotyzmu wypartym przez system represji i stalinowskiego terroru. Obserwując ówczesne stanowisko Ukraińców pisarz notował:

Jakość wojny to jakość organizacji społeczeństwa, narodu. Cały nasz fałsz, cała szarzyzna, całe bezmięsne i bezmózgowe łajdactwo, cały nasz pseudodemokratyzm, przemieszany z satrapostwem, to wszystko wychodzi nam bokiem i pędzi nas, jak suche zioła, przez stepy, przez stepy, przez pustynie. I nad wszystkim tym - „zwyciężymy!” [...] Zresztą, sami jesteśmy pokonani przez bieg historii i koniunktur ekonomicznych ${ }^{22}$.

Pisarz doszedł do wniosku, że właśnie „zacofany styl życia spowodował zacofany styl walki"23.

Dopiero w latach 60. XX wieku postępowo i wybiórczo zaczęto przywracać pamięć doświadczonej na wojnie tragedii jednostki. Dlatego literatura ukraińska wcześniej nie rozliczyła się z militarną praktyką minionej epoki, zostawiając niewypełnioną lukę dla ludzkiego, prywatnego, indywidualnego doświadczenia wojny. Tak samo nie została całkiem zużyta militarna retoryka w ukraińskiej kulturze, prowokując pokusę jej zastosowania dla nowo powołanych celów i funkcji. Obecnie resemantyzacja militarnego dyskursu dokonuje się w kulturze masowej, $\mathrm{w}$ tym także $\mathrm{w}$ powieści popularnej. Idąc śladem opinii Oleksandra Dovženki, możemy zaryzykować stwierdzenie, że ukraińskie doświadczenie walki - właśnie poprzez jego brak i niedoprecyzowanie w przeszłości - zostało użyte w niezwykły sposób i zaktualizowane w ostatnich latach.

Militarna retoryka, pomimo jej stereotypowości i przyswojenia przez nią chwytów kultury masowej, po raz kolejny przemawia do czytelnika zrozumiałym dla niego, w tych okolicznościach, językiem. Wygląda na to, iż nie mamy tu do czynienia wyłącznie $z$ efektem zmiany nieprofanowanych dotychczas stereotypów z kolonialnej przeszłości z charakterystyczną dla nich dominantą walki i agresji wobec Innego. Militarna retoryka wydaje się być odpowiednia dla potrzeb kultury okresu przejściowego, w ramach której nie straciła na znaczeniu, choć nieco zmieniła swoją funkcję. Wypracowane formuły retoryczne nadają się również do określenia okoliczności współczesnych walk informacyjnych, które trzęsą całym światem.

Sytuacja, którą próbujemy zdefiniować poprzez wizje poszczególnych pisarzy, jest sytuacją znajdującą się pomiędzy totalitarną świadomością z przeszłości a zagrożeniami obecnego medialnego militaryzmu. Analiza dwóch popularnych po-

\footnotetext{
22 A. Dovženko, Dnevnikovye zapisi. Ŝčodennykovì zapysy. 1939-1956. Kharkov 2013, s. 223.

${ }^{23}$ Ibidem.
} 
wieści - Pamiętnik ukraińskiego szaleńca Liny Kostenko oraz Wojna i my Sergiya Pantiuka - świadczy o powrocie militarnej retoryki we współczesnej kulturze i literaturze, ale także o jej przewartościowaniu i nowej roli wobec zaistniałych wyzwań XXI wieku. Szaleniec z utworu Kostenko utożsamia się z ofiarą w świecie totalnej agresji i sukcesu, nie będąc w stanie stawić czoła wyzwaniom współczesności, zwłaszcza presji mediów. Odwrotnie, protagonista drugiej powieści, doświadczywszy wojny w okresie młodości wciąż trwa w świadomości walki i strachu przed śmiercią. Świat wspomnień wojny warunkuje jego psychikę, a wyzwolenie $\mathrm{z}$ tej obsesji staje się możliwe tylko za cenę pozbycia się wizji kompletnego zagrożenia i nabycia nowej, absolutnie różnej od poprzedniej, tożsamości. W obu przypadkach mamy do czynienia $\mathrm{z}$ przezwyciężaniem kompleksu wojny, bardzo skomplikowanym w skutkach, ale wręcz niezbędnym. Tak więc trauma wydziedziczenia, wyniesiona z przeszłości, spotyka się z potrzebą nabywania nowej tożsamości, co odpowiadałaby sytuacji postzależności i emancypowania się jednostki po upadku systemu totalitarnego. 